\title{
Comparing Credit Risk in Islamic and Conventional Banking Using Bank-Level Panel Data
}

\author{
Akhmad Akbar Susamto \\ Universitas Gadjah Mada, Yogyakarta, Indonesia \\ email: akhmad.susamto@ugm.ac.id

\section{Danes Quirira Octavio} \\ Universitas Gadjah Mada, Yogyakarta, Indonesia \\ email: danes.quirira.o@mail.ugm.ac.id \\ Dyah Titis Kusuma Wardani \\ Universitas Muhammadiyah Yogyakarta, Indonesia \\ email: dyah.wardani@umy.ac.id
}

\begin{abstract}
This paper investigates if there is a difference in the level of the credit risk of Islamic as compared to the level of credit risk of conventional banks. This paper further investigates the importance of various credit risk determinants and possible differences in how such determinants affect credit risk in Islamic and conventional banking industries. This paper employs dynamic panel regressions using system GMM estimators. The sample includes 11 Islamic and 95 conventional banks in Indonesia throughout 2003-2018. Based on the results, it is concluded that there is no difference in the level of the creditrisk of Islamic as compared to that of conventional banks. It is also concluded that credit risk is significantly affected by current and lagged asset size, lagged financing, current profitability, lagged economic growth, and current inflation. The effect of lagged financing, current profitability, and lagged economic growth is different in Islamic and conventional banking.
\end{abstract}

Keywords: credit risk; islamic bank; conventional bank

Abstrak: Makalah ini menganalisis apakah terdapat perbedaan antara tingkat
risiko kredit pada perbankan syariah dan tingkat risiko kredit pada perbankan
konvensional. Makalah ini selanjutnya juga menganalisis signifikansi faktor-
faktor yang diduga mempengaruhi risiko kredit dan kemungkinan perbedaan
pengaruh faktor-faktor tersebut terhadap risiko kredit pada perbankan syariah
dibandingkan pada perbankan konvensional. Makalah ini menggunakan regresi
panel dinamis dengan system generalized method of moments (GMM)
estimator. Sampel dalam makalah ini mencakup 11 bank syariah dan 95 bank
konvensional di Indonesia selama periode $2003-2018$. Berdasarkan hasil
analisis, dapat disimpulkan bahwa tidak terdapat perbedaan perbedaan antara
tingkat risiko kredit pada perbankan syariah dan tingkat risiko kredit pada
perbankan konvensional. Begitu pula, dapat disimpulkan bahwa risiko kredit

Economica: Jurnal Ekonomi Islam - Volume 11, Nomor 2 (2020) 
Akhmad Akbar Susamto, Danes Quirira Octavio, and Dyah Titis Kusuma Wardani

secara signifikan dipengaruhi oleh ukuran aset tahun ini dan tahun lalu, pembiayaan tahun lalu, profitabilitas tahun ini, pertumbuhan ekonomi tahun lalu dan inflasi tahun ini. Pengaruh pembiayaan tahun lalu, profitabilitas tahun ini, dan pertumbuhan ekonomi tahun lalu, secara khusus berbeda pada perbankan syariah dibandingkan pada perbankan konvensional.

Kata Kunci: resiko kredit; bank syariah; bank konvensional 
Comparing Credit Risk in Islamic and Conventional ...

\section{Introduction}

Banks' credit risk signals crises (Reinhart and Rogoff 2010; Nkusu 2011; Louzis, Vouldis, and Metaxas 2012). However, the chain from credit risk hikes to banks' crises and crises to banking and economic crises is very short. Deterioration in the quality of banks' credit portfolios can destroy the business of the corresponding banks and put the banking system and the economy as a whole into jeopardy.

Investigation on the factors that determine credit risk is hence of essential concern. This is particularly true in countries where Islamic banks exist along with conventional banks. Despite findings currently available in the banking literature (Naili and Lahrichi 2020; Onmus-Baykal 2010), understanding the nature of credit risk faced by Islamic banks compared to credit risk faced by conventional banks remains far from complete. Several authors point out that the Islamic banking industry's profit and loss sharing mechanism brings about inherent risks in Islamic bank operation, one of which is credit risk (Errico and Farahbaksh 2001). Several other authors also point out that credit risk in the Islamic banking industry does not include credit risk in the exactly conventional sense (Elgari 2003; Ardevol et al. 2016). Therefore, credit risk in the Islamic banking industry may be affected differently by its determinants than credit risk in the conventional banking industry.

The majority of studies in the past focus either on the Islamic banking industry (Johansson et al. 2007; Misman et al. 2015; Munn et al. 2015) or the conventional banking industry (Naili and Lahrichi 2020). This hampers the possibility of directly comparing the level of credit risk and how credit risk is affected by its determinants in the two banking industries. More recent studies cover both Islamic and conventional banks in the sample (Abedifar, Molyneux, and Tarazi 2013; Beck, Demirgüç-Kunt, and Merrouche 2013; Kabir, Worthington, and Gupta 2015; Lassoued 2018; Louhichi and Boujelbene 2016) but limit their analysis to the difference in the level of credit risk rather

Economica: Jurnal Ekonomi Islam - Volume 11, Nomor 2 (2020) 
than going further to analyze the relative importance of the determinants of credit risk in the two banking industries. Another study (Akram and Rahman 2018) covers both Islamic and conventional banks in the sample, but instead of making direct comparisons on the level of credit risk and its determinants, it focuses more on credit risk management scenarios.

This paper attempts to analyze if there is a difference in the level of Islamic banks' credit risk compared to the level of the credit risk of conventional banks. This paper further attempts to analyze the statistical importance of various credit risk determinants and the possible difference in how credit risk is affected by such determinants in the Islamic banking industry compared to that in the conventional banking industry. This paper employs dynamic panel regressions with an unbalanced annual panel dataset of commercial banks in Indonesia to achieve its objectives. The sample in this paper includes 11 Islamic and 95 conventional banks, representing nearly 95 percent share of the country's banking industry assets.

The primary finding is that there is no significant difference in Islamic banks' credit risk level compared to that of conventional banks. The other primary finding is that credit risk is significantly affected by current and lagged asset size, lagged financing, current profitability, lagged economic growth, and current inflation. Here, the way lagged financing, current profitability, and lagged economic growth affect credit risk differs in Islamic and conventional banking industries.

This paper relates to the existing literature in the following way. Firstly, similar to that of Kabir et al. (2015), Louhichi \& Boujelbene (2016), and Lassoued (2018), it presents evidence on the level of the credit risk of Islamic banks as directly compared to the credit risk of conventional banks. However, in contrast to these works measuring credit risk using the distance-to-default (DD) and/or Z-score, respectively, this paper relies exclusively on Non Performing Financing (NPF) and Non Performing Loans (NPL) ratio as a measure of credit risk. This paper also differs from the above works in that it 
extends the analysis of credit risk by looking at possible differences in the way credit risk is affected by its determinants in Islamic and conventional banking industries. Secondly, this paper compares the level of credit risk in Islamic and conventional banking industries in Indonesia rather than examining crosscountry data (Kabir, Worthington, and Gupta 2015; Louhichi and Boujelbene 2016). This paper, in this regard, complements previous works focusing on single country data, such as the ones on Malaysia (Lassoued 2018) and Pakistan (Akram and Rahman 2018). Single country data allow for less unobserved heterogeneity in the factors that affect credit risk, reducing potential bias in the analysis..

\section{Literature review}

Following the Basel Committee on Banking Supervision (BCSB), credit risk is defined as the potential that a bank borrower or counterparty fails to meet its obligations following agreed terms. In the conventional banking industry, credit risk is unequivocally associated with the lending activities of banks. It simply reflects the risk of loans not being repaid. Credit risk is associated with banks' financing activities conditional on the schemes applied (Elgari 2003; Ardevol et al. 2016). The financing schemes include mainly mudarabah, musharakah, ijara and murabahah.

Mudarabah is a financing contract in which a bank provides capital to its partners through a pre-agreed profit-sharing arrangement. Any profit will be shared according to the agreed arrangement, while the bank will bear the loss on the condition that it is not caused by partners' negligence (Fatihah, Kebangsaan, and Permata 2019). Meanwhile, musharakah is a joint venture contract in which two parties -a bank and its partners- contribute capital and managerial ability in a pre-agreed arrangement. Any profit will be shared according to the agreed arrangement, while the loss will be shared according to the proportion of the capital contributed (Samad, Gardner, and Cook 2005). Credit risk in mudarabah and musharakah arises from the potential that

Economica: Jurnal Ekonomi Islam - Volume 11, Nomor 2 (2020) 
bank's partners fail to make payments due to incompetence in managing the business. This is pertinent, especially in the presence of adverse selection. Besides, the risk arises from the fact that there is asymmetric information between the bank and its partners (who actively manage the business), opening the chance for fraud. Ijarah is a contract in which a bank leases out an asset to its lessee and receives rent payments over a specified period. Credit risk in ijarah arises from the potential that bank lessees fail to make payments when rent is due. Lastly, Murabaha is a contract in which a bank buys an investment good specified by its clients and sells it with an agreed margin. Payments are then made in installment or lump sum at a future date (Samad, Gardner, and Cook 2005). Credit risk in murabahah arises from the potential that the bank's clients fail to make installment payments or lump sums according to the agreed terms. Credit risk in murabahah is similar to credit risk from banks' lending activities in the conventional banking industry.

Thus, it is clear that credit risk in the Islamic banking industry does not include credit risk in the conventional sense. However, it shares the crucial feature of credit risk in the conventional banking industry, namely the potential of capital impairment.

Theoretically, it can be expected that the level of credit risk in the Islamic banking industry is higher than the level of credit risk in the conventional banking industry. In the presence of adverse selection, it is the tendency of those whose business is particularly risky or those with less competence in managing the business to demand mudarabah and musharakah from Islamic banks. Besides, asymmetric information between the banks and their partners in mudarabah and musharakah schemes also opens the chance for fraud. These will increase the potential that banks' partners will fail to make payments and the probability of banks having impaired capital (Khan 2010). Empirical evidence reported by Kabir et al. (2015) and Lassoued (2018) supports the above theoretical prediction that credit risk in Islamic banking is higher than credit risk in conventional banking. 
Further, as credit risk in the Islamic banking industry does not include credit risk in the exactly conventional sense (Elgari 2003; Ardevol et al. 2016), theoretically, it is possible that the way credit risk is affected by its determinants in the Islamic banking industry differs from that in the conventional banking industry. Therefore, to follow previous studies identifying different factors that affect credit risk (S. Ghosh 2015; Louzis, Vouldis, and Metaxas 2012; Johansson et al. 2007), the determinants of credit risk consist of bank-specific macroeconomic variables.

The importance of credit risk of bank-specific variables can be explained within several different hypotheses. The most central are hypotheses derived from the agency theory framework (Jensen and Meckling 1976). This framework discusses a situation where one party (the principal) engages another party (the agents) to perform tasks on her behalf. Since the incentives faced by the principal and the agents are not perfectly aligned and the principal tends to be less informed than the agents, the agents may consequently be tempted to act in their interest rather than in the interest of the principal.

Based on the agency theory framework, it can be expected that the size of banks' assets affects credit risk negatively. A larger asset size allows banks to diversify. A larger asset size also allows banks to develop better systems of information. This improves the quality of loan management and increases the possibility of disclosing managers' unobservable behaviors concerning loan underwriting and monitoring (Johansson et al. 2007). Nonetheless, according to the "too big to fail" hypothesis (Stern and Feldman 2004). "Too big to fail" refers to the notion that larger banks are too vital to the economy that it would be dreadful if the government let them go bankrupt. Knowing that they would be saved in the event of failure, larger banks may opt to reduce their loan management efforts. This may lead to lower quality of loan portfolios and, consequently, increases credit risk. Empirical evidence in Haryono, Ariffin, and Hamat (2016), Zribi and Boujelbène (2011), and several other studies

Economica: Jurnal Ekonomi Islam - Volume 11, Nomor 2 (2020) 
tend to support the "diversification" hypothesis over the "too big to fail" hypothesis.

Irrespective of whether a bank uses its capital or relies on savers' deposits to fund lending, the rate of return required by its shareholders remains typically high. Facing this incentive, managers will behave differently in different capital conditions. For example, managers will limit loans to less risky portfolios when the bank's capital ratio is high and has ample financial capital to fund lending. By contrast, when the bank's capital is eroded, and the bank has to rely on savers' deposits to fund lending, managers will tolerate riskier loan portfolios to achieve the required rate of return (Berger and DeYoung 1997). Thus, the expectation is that the effect of bank capital on credit risk is negative.

Following two competing hypotheses, namely "bad management" and "skimping" hypotheses, there are two explanations for how inefficiency affects credit risk. The first explanation is based on the idea that higher inefficiency reflects bad cost management practices and that a bank suffering from such practices may also suffer from lousy loan management practices. Managers who cannot fully perform cost management may also be unable to perform loan underwriting and monitoring fully. Thus, based on this "bad management" hypothesis, it is likely that inefficiency has a positive relationship with credit risk (Berger and DeYoung 1997). The second explanation is based on the idea that higher inefficiency requires cost-cutting practices and that a bank committing such practices may have to devote fewer resources for loan management. The skimping on the resources devoted to underwriting and monitoring loans bears the consequences of more considerable credit risk in the future. Thus, based on this "skimping" hypothesis, it is likely that inefficiency has a negative relationship with credit risk (Berger and DeYoung 1997). In Salas and Saurina (2002), it is reported that the effect of efficiency on credit risk is not significant. Other empirical evidence, however, tends to favor the "bad management" (Berger and 
DeYoung 1997; Louzis, Vouldis, and Metaxas 2012; Podpiera and Weill 2008) over the "skimping" hypothesis.

Existing studies highlight two opposing hypotheses for effect on the credit risk of income diversification. The first hypothesis is the "diversification" hypothesis. Banks with more diversified income can generate income from sources other than lending, such as payments and brokerage. These banks, therefore, have fewer incentives to get involved in speculative projects. Moreover, compared to their peers whose income is less diversified, banks with more diversified income may benefit from informational-cost synergies and the expansion of client relationships (Abedifar et al. 2015), which in turn reduce their credit risk. Thus, based on the "diversification" hypothesis, income diversification associates negatively with credit risk.

Nonetheless, having more diversified activities may induce conflicts of interest. It may also complicate banks' activities monitoring (Barth, Caprio, and Levine 2004) such that the quality of loan portfolios deteriorates. Thus, following this "complexity" hypothesis, the effect on the credit risk of income diversification is positive. However, research by Stiroh (2004) and Louzis et al. (2012) reported that the effect of income diversification on credit risk is not significant. Meanwhile, the evidence in Abedifar et al. Abedifar et al. (2015) indicates that the effect of income diversification on credit risk is negative, lending support for the "diversification" hypothesis over the "complexity" hypothesis.

Banks are engaged in loan market share competitions. To boost market share, banks may upsurge their loan growth, either by trimming down the interest rate they charge, downgrading the loan requirements, or both (Keeton 1999). This increases the possibility of the banks having low-quality loan portfolios. Moreover, an upsurge in loans growth reduces banks' ability to scrutinize loans. Therefore, banks with higher loans growth have to deal with higher credit risk than their peers with lower loans growth. Empirical studies Espinoza and Prasad (2010), Jimenez and Saurina (2006), and

Economica: Jurnal Ekonomi Islam - Volume 11, Nomor 2 (2020) 
Quagliariello (2007) find a significant effect of credit expansion on credit risk. It is accordingly expected that the effect of loans growth on credit risk is positive.

Back to the agency theory framework. Profit indicates a healthy principalagent relationship. Managers working for highly profitable banks are less need to create revenue than their peers working for banks with a lower profit. This reduces their incentives to take more risk from lending. Empirical evidence in Ghosh (2015), Chaibi and Ftiti (2015), and Haryono, Ariffin, and Hamat (2016) substantiate the idea that banks with a higher profit have lower credit risk than their peers with a lower profit (Boudriga, Taktak, and Jellouli 2009). It is therefore expected that the effect of profitability on credit risk is negative.

The importance of credit risk of macroeconomic variables can be explained within the framework of the life-cycle consumption model. Lawrence (1995) uses a two-period life-cycle consumption model to study the impact of a default option. The option causes a kink in both the line of the budget and the indifference curve, implying that individuals with different income levels will have different optimal consumptions. In periods of slower economic growth, borrowers experience a higher risk of facing unemployment. Borrowers will therefore have higher rates of default. By contrast, borrowers will have lower default rates in periods of faster economic growth as they experience a lower risk of facing unemployment. Taking an additional assumption that individuals borrow from banks to invest in tangible or financial assets, Rinaldi and Sanchis-Arellano (2006) extend Lawrence's model and show that changes in the lending market structure significantly affect the amount of borrowing. In addition to economic growth, other macroeconomic variables such as unemployment and inflation are also crucial for credit risk as they can worsen the indebtedness to income ratio. Empirical evidence suggests that the effect of economic growth on credit risk is always negative (Tripodi 2001; Dimitrios, Helen, and Mike 2016; Chaibi and Ftiti 2015; S. Ghosh 2015; Louhichi and Boujelbene 2016). The effects of 
unemployment and inflation are respectively positive and negative but not always significant.

Many banks belong to individual investors. Large-block shareholders own many others. The concentration of ownership may increase shareholders' incentive to monitor banks' performance Junarsin and Ismiyanti 2009) and impose management discipline. As a result, banks with more concentrated ownership are better managed and have a more conservative attitude toward risk than those with dispersed ownership. Empirical evidence supports this prediction (Shehzad, de Haan, and Scholtens 2010; Barry, Lepetit, and Tarazi 2011). It can therefore be expected that ownership concentration relates negatively to credit risk.

Despite objectives to address market failures and maximize social welfare, government-owned banks may suffer from politically induced misallocation of loans (Banerjee 1997; Hart, Shleifer, and Vishny 1997). Banks owned by the government may therefore have higher credit risk relative to those owned by private enterprises. Earlier empirical studies report inconsistent results. Iannotta, Nocera, and Sironi (2007) and Iannotta, Nocera, and Sironi (2013) find that government-owned banks are highly associated with credit risk, while Brown and Dinç (2011) and Cornett et al. (2010) find reverse results. $\mathrm{Hu}, \mathrm{Li}$, and Chiu (2004) indicate that government ownership and credit risk depend on the shareholding ratio.

As credit risk in the Islamic banking industry does not include credit risk in the exactly conventional sense (Elgari 2003; T. Khan and Ahmed 2001), the way it is affected by bank-specific and macroeconomic variables above may differ compared to credit risk in the conventional banking industry.

\section{Methods}

The data in this paper span between 2003 and 2018. By the end of this period, there were 113 commercial banks in Indonesia. However, seven banks are left out of the sample due to a recent merger or recent conversion from

Economica: Jurnal Ekonomi Islam - Volume 11, Nomor 2 (2020) 
conventional to Islamic banks. Thus, the final sample includes 106 banks, which consist of 11 Islamic and 95 conventional banks.

The data are analyzed using dynamic panel regressions based on system generalized method of moments (GMM) estimators (Arellano and Bover 1995; Blundell and Bond 1998). These estimators permit not only to rely on internal instruments to control endogeneity problems but also to include time-invariant regressors.

The primary regression equation is given by

$$
\begin{aligned}
& Y_{i, t}=\alpha+\delta Y_{i, t-1}+\sum_{j=1}^{J} \beta_{2 j} X_{i, t-s}^{j}+\sum_{k=1}^{K} \beta_{1 k} X_{i, t-s}^{k}+ \\
& \sum_{d=1}^{D} \beta_{3 d} X_{i, t-s}^{d}+\varepsilon_{i, t}
\end{aligned}
$$

where $Y_{i, t}$ denotes the logit transformation of NPF or NPL ratio for bank $i$ at the end of period $t$ and $Y_{i, t-1}$ denotes the dependent variable lagged by one period. The alphabet $X^{j}$ denotes a vector of bank-specific variables, while $X^{k}$ Denotes a vector of macroeconomic variables. The alphabet $X^{d}$ Denotes a vector of dummy variables, one of which is a dummy valued one if the bank is an Islamic bank and 0 otherwise. The alphabets $\delta$ and $\beta$ s denote the coefficients to be estimated in the regression and $\varepsilon_{i, t}$ Denotes the error term.

The critical variable of interest, credit risk, is measured using either non performing financing (NPF) or non performing loans (NPL) ratio. NPF refers to the proportion of financing in default or close to default in Islamic banking, while NPL refers to a similar proportion in conventional banking. Despite several criticisms, NPF and NPL are economically intuitive and very popular Kabir et al. (2015) and Haryono et al. (2016) for other uses of NPF ratio and Berger and DeYoung (1997), Hippolyte (2005) and Ghosh (2015) for other uses of NPL ratio. Following Espinosa and Prasad (2011), Klein (2013), and Ghosh (2015), NPF and NPL ratios are further expressed as $\log (\mathrm{NPF} /(1-\mathrm{NPF})$ ) or $\log (\mathrm{NPL} / 1-\mathrm{NPL}))$. Such transformation allows the value of credit risk to 
span and be distributed symmetrically over the interval $[-\infty ;+\infty]$ instead of just $[0.0 ;+1]$. Such transformation also prevents the presence of nonnormality in the error term and accounts for possible nonlinearities.

The vector of bank-specific variables consists of bank asset size, capitalization, efficiency, financing or loan growth, income diversification, inefficiency, and profitability. Bank size, capitalization, and efficiency are measured using the log of total assets, the equity-to-total-assets ratio, and the noninterest-expenses-to-total-assets ratio. Financing or loan growth is measured using the financing-to-total-assets ratio. Finally, income diversification is measured using the noninterest-incomes-to-total-operatingincomes ratio, while profitability is proxied using the net-pre-tax-income-tototal-assets ratio (commonly known as return on assets, ROA).

The data for bank-specific variables are obtained from audited financial reports published by each bank. These reports have been prepared and presented standardized, making it possible to have meaningful comparisons over time and across banks.

The vector of macroeconomic variables consists of economic growth, unemployment, and inflation. Economic growth is measured using real GDP growth. Unemployment refers to the percentage of unemployed in the labor force. However, rather than its original measure, unemployment is expressed as the percent change in the unemployed labor force. Inflation, which refers to the increase in the price level over time, is expressed as the percent change in the consumer price index (CPI). The data for economic growth, unemployment, and inflation are obtained from the Statistics Agency of Indonesia (BPS).

To take into account the effects of ownership concentration and ownership status, four dummy variables are constructed. The first is a dummy value of 1 if the largest share of a bank's ownership is more than 50 percent and 0 otherwise. The second is a dummy valued one if a bank is owned by 
foreign entities and 0 otherwise. The third is a dummy taking the value one if local governments and 0 own a bank otherwise, while the fourth is a dummy valued one if a bank is owned by the central government and 0 otherwise. Table 1 provides a brief description of the above variables and their summary statistics.

In the regression estimations, bank-specific variables are treated as weakly exogenous. Their values are assumed to be affected by the past NPF or NPL ratio but not by the current. For these variables, only current and lagged values can be used as valid instruments. Macroeconomic variables are treated as strictly exogenous. Their past and future values are assumed to not correlate with the error term. Similarly, dummy variables are treated as strictly exogenous, meaning that their past and future values are assumed uncorrelated with the error term.

Table 1. Description of variables

\begin{tabular}{|c|c|c|c|c|}
\hline Variables & Description & Source & Mean & $\mathbf{N}$ \\
\hline \multicolumn{5}{|c|}{ Bank specific variables } \\
\hline Size & Log of total assets & OJK & 16.189 & 1,217 \\
\hline Capitalization & Equity-to-assets-ratio & OJK & 0.143 & 1,217 \\
\hline Inefficiency & $\begin{array}{l}\text { Noninterest-expenses-to- } \\
\text { assets ratio }\end{array}$ & OJK & 0.052 & 1,217 \\
\hline Financing growth & Financing-to-assets ratio & OJK & 0.617 & 1,217 \\
\hline Income div. & $\begin{array}{l}\text { Nonfinancing income-to-op } \\
\text { income ratio }\end{array}$ & OJK & 0.144 & 1,217 \\
\hline Profitability & $\begin{array}{l}\text { Net-pre-tax-income-to-assets } \\
\text { ratio }\end{array}$ & OJK & 1.789 & 1,217 \\
\hline \multicolumn{5}{|c|}{ Macroeconomic variables } \\
\hline Economic growth & Percent change in real GDP & BPS & 5.458 & 1,217 \\
\hline Unemployment & $\begin{array}{l}\text { Percent change in the labor } \\
\text { force unemployed }\end{array}$ & BPS & -4.092 & 1,217 \\
\hline Inflation & $\begin{array}{l}\text { Percent change in the } \\
\text { consumer price index }\end{array}$ & BPS & 5.712 & 1,217 \\
\hline
\end{tabular}


Arellano-Bond tests for zero autocorrelation are conducted to ensure that the results are consistent and no second-order serial correlation exists in the first difference of the error terms. Besides, to ensure the validity of the lagged dependent variable and some other variables as instruments, Sargan tests of overidentification are also conducted. Finally, pre-estimation checks using Fisher-type Augmented Dickey-Fuller (ADF) tests indicate that all nondummy bank-specific and macroeconomic variables are stationary, meaning that their mean, variance, and autocovariance are invariant over time.

\section{Result and discussion}

Table 2 presents the basic regression results. In column 1, only bankspecific variables are included in the regression. The lagged dependent variable is a dummy for Islamic banks, a dummy for 50 percent ownership concentration, and a dummy for foreign banks and local-government-owned banks, central-government-owned banks, respectively. In column 2, macroeconomic variables are added to the regression. Finally, in column 3, a dummy for the 2008 global financial crisis and a dummy for the post-global financial crisis are also added into the regression. Pointedly, in these three columns, the coefficient of the lagged dependent variable is significant at the 1 percent level. The dynamic specification of the regression is thus justified.

The coefficient of the dummy for Islamic banks is not statistically significant. Therefore, there is no indication that the level of the credit risk of Islamic banks differs from the level of the credit risk of conventional banks. This contrasts with the findings in Kabir et al. (2015) and Lassoued (2018). For example, Kabir et al. (2015) find that Islamic banks have significantly lower credit risk when DD measures credit risk but higher credit risk when Zscore and NPF ratio are used instead. Similarly, Lassoued (2018) finds that the level of the credit risk of Islamic banks is higher than the level of the credit risk of conventional banks.

Economica: Jurnal Ekonomi Islam - Volume 11, Nomor 2 (2020) https://journal.walisongo.ac.id/index.php/economica 
Akhmad Akbar Susamto, Danes Quirira Octavio, and Dyah Titis Kusuma Wardani

Table 2. The difference in the level of credit risk

\begin{tabular}{|c|c|c|c|}
\hline & \multicolumn{3}{|c|}{ System GMM Estimators } \\
\hline & Regression 1 & Regression 2 & Regression 3 \\
\hline \multirow[t]{2}{*}{ Lagged dependent variable } & $0.647^{* * *}$ & $0.637^{* * *}$ & $0.627^{* * *}$ \\
\hline & $(0.057)$ & $(0.060)$ & $(0.059)$ \\
\hline \multirow[t]{2}{*}{ Dummy for Islamic banks } & -0.043 & -0.035 & -0.036 \\
\hline & $(0.166)$ & $(0.136)$ & $(0.146)$ \\
\hline \multirow[t]{2}{*}{ Bank asset size } & $-0.681^{* *}$ & $-0.764^{* *}$ & $-0.763^{* *}$ \\
\hline & $(0.305)$ & $(0.292)$ & $(0.294)$ \\
\hline \multirow[t]{2}{*}{ Bank asset size $(\mathrm{t}-1)$} & $0.696^{* *}$ & $0.825^{* * *}$ & $0.824^{* * *}$ \\
\hline & $(0.278)$ & $(0.277)$ & $(0.283)$ \\
\hline \multirow[t]{2}{*}{ Bank capitalization } & -1.039 & -0.917 & -0.621 \\
\hline & $(1.449)$ & $(1.360)$ & $(1.318)$ \\
\hline \multirow[t]{2}{*}{ Bank capitalization $(\mathrm{t}-1)$} & -0.447 & -0.136 & 0.028 \\
\hline & $(1.666)$ & $(1.558)$ & $(1.612)$ \\
\hline \multirow[t]{2}{*}{ Bank inefficiency } & -0.945 & -1.541 & -1.884 \\
\hline & $(2.080)$ & $(2.077)$ & $(1.695)$ \\
\hline \multirow[t]{2}{*}{ Bank inefficiency $(\mathrm{t}-1)$} & -2.051 & -2.406 & $-2.839^{*}$ \\
\hline & $(1.858)$ & $(1.690)$ & $(1.698)$ \\
\hline \multirow[t]{2}{*}{ Bank financing } & $-1.148^{*}$ & -0.951 & -0.698 \\
\hline & $(0.643)$ & $(0.596)$ & $(0.598)$ \\
\hline \multirow{2}{*}{ Bank financing $(\mathrm{t}-1)$} & $2.391^{* * *}$ & $2.274^{* * *}$ & $2.660 * * *$ \\
\hline & $(0.621)$ & $(0.656)$ & $(0.701)$ \\
\hline \multirow[t]{2}{*}{ Bank income diversification } & 0.556 & 0.531 & 0.693 \\
\hline & $(0.486)$ & $(0.487)$ & $(0.431)$ \\
\hline \multirow[t]{2}{*}{ Bank income diversification $(\mathrm{t}-1)$} & -1.012 & -0.737 & -0.466 \\
\hline & $(0.796)$ & $(0.828)$ & $(0.867)$ \\
\hline \multirow[t]{2}{*}{ Bank profitability } & $-0.099 * *$ & $-0.094^{* *}$ & $-0.090^{* *}$ \\
\hline & $(0.049)$ & $(0.047)$ & $(0.045)$ \\
\hline \multirow[t]{2}{*}{ Bank profitability $(t-1)$} & 0.002 & 0.001 & -0.000 \\
\hline & $(0.003)$ & $(0.003)$ & $(0.003)$ \\
\hline \multirow[t]{2}{*}{ Economic growth } & & -0.019 & -0.028 \\
\hline & & $(0.066)$ & $(0.062)$ \\
\hline \multirow[t]{2}{*}{ Economic growth $(\mathrm{t}-1)$} & & $-0.159 * *$ & $-0.139 *$ \\
\hline & & $(0.078)$ & $(0.081)$ \\
\hline \multirow[t]{2}{*}{ Unemployment } & & -0.002 & -0.001 \\
\hline & & $(0.004)$ & $(0.005)$ \\
\hline \multirow[t]{2}{*}{ Unemployment $(\mathrm{t}-1)$} & & 0.006 & 0.005 \\
\hline & & $(0.004)$ & $(0.004)$ \\
\hline \multirow[t]{2}{*}{ Inflation } & & $0.033^{* * *}$ & $0.021 *$ \\
\hline & & $(0.010)$ & $(0.011)$ \\
\hline \multirow[t]{2}{*}{ Inflation (t-1) } & & $0.021^{* *}$ & 0.015 \\
\hline & & $(0.009)$ & $(0.011)$ \\
\hline $\mathrm{N}$ observations & 1,217 & 1,217 & 1,217 \\
\hline $\mathrm{N}$ banks & 106 & 106 & 106 \\
\hline Second order test & 0.849 & 0.877 & 0.876 \\
\hline Hansen test & 0.211 & 0.184 & 0.284 \\
\hline \multicolumn{4}{|c|}{$\begin{array}{l}\text { Note: Each regression includes a constant, a dummy for } 50 \text { percent ownership concentration, a } \\
\text { dummy for foreign banks, a dummy for local-government-owned banks and a dummy for central- } \\
\text { government-owned banks. In addition, regression } 3 \text { includes a dummy for the } 2008 \text { global financial } \\
\text { crisis and a dummy for post crisis. Values in parentheses refer to robust standard errors. }{ }^{* *},{ }^{* *} \text { and } \\
{ }^{*} \text { denote significance at the } 1,5 \text { and } 10 \text { percent level respectively. }\end{array}$} \\
\hline
\end{tabular}


One possible explanation for the no-difference finding in this paper is that the share of the Islamic banking industry to the entire national banking industry in Indonesia is too tiny compared to the share of the Islamic banking industry in Malaysia and Pakistan. By the end of 2018, the share of the Islamic banking industry to the entire national banking industry in Indonesia is just below six percent. Therefore, the behaviors and decisions in the Islamic banking industry remain heavily shadowed by the behaviors and decisions in the conventional banking industry.

The coefficients of current and lagged asset size are both significant at the 5 percent level. These coefficients' negative and positive signs indicate that current asset size reduces credit risk, while lagged asset size increases credit risk. This may indicate a more complex relationship between asset size and credit risk, beyond the "diversification" versus the "too big to fail" hypotheses.

The coefficient of lagged financing is positive and significant at the 1 percent level. Thus, in line with previous findings in Jimenez and Saurina (2005), Quagliariello (2007), and Espinoza and Prasad (2010), credit risk increases as financing increases.

The coefficient of current profitability is negative and significant at the 5 percent level. Holding other variables constant, credit risk tends to decrease as current profitability increases. This is consistent with the findings in Ghosh (2015), Chaibi and Ftiti (2015), and Haryono et al. (2016).

The coefficient of lagged economic growth is negative and significant at least at the 10 percent level. This is in line with previous findings Messai and Jouini (2013), Chaibi and Ftiti (2015), Dimitrios et al. (2016), Ghosh (2015), Loihichi and Boujelbene (2016) that the higher economic growth, the lower is credit risk. The coefficient of current inflation is positive and significant at different percentage levels. This indicates that lagged inflation matters for credit risk. Holding other variables constant, an increase in current inflation will increase credit risk.

Economica: Jurnal Ekonomi Islam - Volume 11, Nomor 2 (2020) 
To analyze if there is a difference in the way current and lagged asset size, lagged financing, current profitability, lagging economic growth, and current inflation affect credit risk in Islamic as compared to the conventional banking industry, this paper reemploys dynamic panel regressions in equation (1) with two interaction terms. The first is an interaction term between the Islamic bank dummy and "current" bank-specific or macroeconomic variables. The second is an interaction term between the Islamic bank dummy and "lagged" bank-specific or macroeconomic variables.

Table 3 presents the results from regressions with interaction terms between the Islamic bank dummy and current and lagged bank-specific variables. In column 1 , the interaction term coefficient between the Islamic bank dummy and current asset size is significant at the 10 percent level. This indicates a difference in the current effect that asset size has on credit risk in Islamic as compared to the conventional banking industry. The positive sign of the interaction terms' coefficients indicates that holding other variables constant, credit risk tends to increase more in Islamic than in the conventional banking industry as current asset size increases. Meanwhile, the interaction term coefficient between the Islamic bank dummy and lagged asset size is not significant. Thus, there is no indication that the way credit risk is affected by lagged asset size is different in Islamic compared to the conventional banking industry.

In column 4, the coefficients of the interaction terms between the Islamic bank dummy and lagged financing are significant at the 5 percent level. This implies a significant difference in how credit risk in Islamic and conventional banking industries is affected by lagged financing. Holding other variables constant, credit risk tends to increase more in Islamic than in the conventional banking industry as the lagged financing increases. In column 6, the coefficients of the interaction terms between the Islamic bank dummy and current profitability are significant at the 1 percent level. This suggests that 
credit risk in Islamic and conventional banking industries is different in how they are affected by current profitability.

Table 3. Difference in the way bank-specific variables affect credit risk

\begin{tabular}{|c|c|c|c|}
\hline & \multicolumn{3}{|c|}{ System GMM Estimators } \\
\hline & Regression 1 & Regression 2 & Regression 3 \\
\hline Dummy for Islamic banks & $\begin{array}{l}-5.833 \\
(4.174)\end{array}$ & $\begin{array}{l}0.590^{*} \\
(0.308)\end{array}$ & $\begin{array}{l}0.288^{*} \\
(0.173)\end{array}$ \\
\hline D Islamic*Bank asset size & $\begin{array}{l}0.986^{*} \\
(0.590)\end{array}$ & & \\
\hline D Islamic*Bank asset size $(\mathrm{t}-1)$ & $\begin{array}{l}-0.633 \\
(0.416)\end{array}$ & & \\
\hline D Islamic*Bank capitalization & & $\begin{array}{l}-5.406^{* * *} \\
(1.786)\end{array}$ & \\
\hline D Islamic*Bank capitalization $(\mathrm{t}-1)$ & & $\begin{array}{l}0.525 \\
(2.504)\end{array}$ & \\
\hline D Islamic*Bank inefficiency & & & $\begin{array}{l}-0.014 \\
(3.396)\end{array}$ \\
\hline D Islamic*Bank inefficiency $(t-1)$ & & & $\begin{array}{l}-6.275^{* * *} \\
(1.929)\end{array}$ \\
\hline $\mathrm{N}$ observations & 1,217 & 1,217 & 1,217 \\
\hline $\mathrm{N}$ banks & 106 & 106 & 106 \\
\hline Second order test & 0.860 & 0.831 & 0.807 \\
\hline \multirow[t]{3}{*}{ Sargan test } & 0.356 & 0.432 & 0.358 \\
\hline & \multicolumn{3}{|c|}{ System GMM Estimators } \\
\hline & Regression 4 & Regression 5 & Regression 6 \\
\hline D Islamic*Bank financing & $\begin{array}{l}3.667 * * \\
(1.744)\end{array}$ & & \\
\hline D Islamic*Bank financing $(\mathrm{t}-1)$ & $\begin{array}{l}7.611^{* *} \\
(3.334)\end{array}$ & & \\
\hline D Islamic*Bank income diver & & $\begin{array}{l}-2.515^{*} \\
(1.351)\end{array}$ & \\
\hline D Islamic*Bank income diver $(t-1)$ & & $\begin{array}{l}-0.598 \\
(1.592)\end{array}$ & \\
\hline D Islamic*Bank profitability & & & $\begin{array}{l}-0.155^{* * *} \\
(0.057)\end{array}$ \\
\hline D Islamic*Bank profitability $(\mathrm{t}-1)$ & & & $\begin{array}{l}0.048 \\
(0.035)\end{array}$ \\
\hline $\mathrm{N}$ observations & 1,217 & 1,217 & 1,217 \\
\hline $\mathrm{N}$ banks & 106 & 106 & 106 \\
\hline Second order test & 0.757 & 0.907 & 0.774 \\
\hline Sargan test & 0.255 & 0.358 & 0.267 \\
\hline $\begin{array}{l}\text { Note: Each regression includes a const } \\
\text { dummy for foreign banks, a dummy } \\
\text { central-government-owned banks. In a } \\
\text { macroeconomic variables, a dummy fo } \\
\text { crisis. Values in parentheses refer to } \\
\text { at the } 1,5 \text { and } 10 \text { percent level respec }\end{array}$ & $\begin{array}{l}\text { t, a dummy for } 5 \\
\text { r local-governm } \\
\text { lition, each regre } \\
\text { the } 2008 \text { global } \\
\text { oust standard er } \\
\text { ely. }\end{array}$ & $\begin{array}{l}\text { percent ownersl } \\
\text { nt-owned banks } \\
\text { ion includes ban } \\
\text { nancial crisis an } \\
\text { rs. }{ }^{* *},{ }^{* *} \text { and }{ }^{*}\end{array}$ & $\begin{array}{l}\text { p concentration, } \\
\text { and a dummy fo } \\
\text { specific variables } \\
\text { a dummy for pos } \\
\text { enote significance }\end{array}$ \\
\hline
\end{tabular}

Economica: Jurnal Ekonomi Islam - Volume 11, Nomor 2 (2020) 
Even though the effect of current capitalization, lagged inefficiency, and current financing on credit risk, in general, is not statistically significant, there is a likelihood that their effect differs on credit risk in Islamic as compared to the conventional banking industry. For example, in column 2 , the coefficients of the interaction terms between the Islamic bank dummy and current capitalization are significant. Similarly, in columns 3 and 4, the interaction term coefficient between the Islamic bank dummy and lagged inefficiency and between the Islamic bank dummy and current financing is significant at the 1 and 5 percent level, respectively.

Table 4. Difference in the way macroeconomic variables affect credit risk

\begin{tabular}{|c|c|c|c|}
\hline & \multicolumn{3}{|c|}{ System GMM Estimators } \\
\hline & Model 1 & Model 2 & Model 3 \\
\hline Dummy for Islamic banks & $\begin{array}{l}0.181 \\
(0.970)\end{array}$ & $\begin{array}{l}-0.052 \\
(0.181)\end{array}$ & $\begin{array}{l}-0.300 \\
(0.390)\end{array}$ \\
\hline D Islamic banks * Ec growth & $\begin{array}{l}-0.349^{* *} \\
(0.152)\end{array}$ & & \\
\hline D Islamic * Ec growth $(\mathrm{t}-1)$ & $\begin{array}{l}0.296^{* *} \\
(0.136)\end{array}$ & & \\
\hline D Islamic * Unemployment & & $\begin{array}{l}-0.002 \\
(0.013)\end{array}$ & \\
\hline D Islamic * Unemployment $(\mathrm{t}-1)$ & & $\begin{array}{l}0.006 \\
(0.012)\end{array}$ & \\
\hline D Islamic * Inflation & & & $\begin{array}{l}-0.018 \\
(0.032)\end{array}$ \\
\hline D Islamic * Inflation $(\mathrm{t}-1)$ & & & $\begin{array}{l}0.057^{* *} \\
(0.029)\end{array}$ \\
\hline $\mathrm{N}$ observations & 1,217 & 1,217 & 1,217 \\
\hline $\mathrm{N}$ banks & 106 & 106 & 106 \\
\hline Second order test & 0.885 & 0.869 & 0.875 \\
\hline Sargan test & 0.361 & 0.355 & 0.259 \\
\hline \multicolumn{4}{|c|}{$\begin{array}{l}\text { Note: The dependent variable is the logit transformation of NPF or NPL ratio. Each regression } \\
\text { includes a constant, a dummy for } 50 \text { percent ownership concentration, a dummy for foreign } \\
\text { banks, a dummy for local-government-owned banks and a dummy for central-government- } \\
\text { owned banks. In addition, each regression includes bank specific variables, macroeconomic } \\
\text { variables, a dummy for the } 2008 \text { global financial crisis and a dummy for post global financial } \\
\text { crisis. Bank specific variables are assumed to be predetermined, while dummies and } \\
\text { macroeconomic variables are all assumed to be strictly exogenous. Values in parentheses refer } \\
\text { to robust standard errors. The asterisks }{ }^{* * *},{ }^{* *} \text { and }{ }^{*} \text { denote significance at the } 1,5 \text { and } 10 \\
\text { percent level respectively. }\end{array}$} \\
\hline
\end{tabular}


Table 4 presents the results from regressions with interaction terms between the Islamic bank dummy and current and lagged macroeconomic variables. In column 1, the coefficients of the interaction terms between the Islamic bank dummy and lagged economic growth is significant at the 5 percent level. The positive sign of the interaction terms' coefficients indicates that holding other variables constant, credit risk tends to increase more in Islamic than in conventional banking industry as the lagged economic growth increases. In column 3, the interaction term coefficient between the Islamic bank dummy and current inflation is not significant. There is thus no significant difference in the way credit risk in Islamic and conventional banking industries is affected by current inflation.

Even though the effect of current economic growth and lagged inflation on credit risk, in general, is not statistically significant, there is a likelihood that their effect differs on credit risk in Islamic compared to credit risk in the conventional banking industry. This is because the coefficients of the interaction terms between these two variables and the Islamic bank dummy are respectively significant at the 5 percent level.

\section{Conclusion}

This paper has compared the level of credit risk and how much risk is affected by its determinants in Islamic and conventional banking industries. Based on the results, it is concluded that there is no significant difference in the level of the credit risk of Islamic banks compared to the level of the credit risk of conventional banks. It is also concluded that credit risk is significantly affected by current and lagged asset size, lagged financing, current profitability, lagged economic growth, and current inflation. Lagged financing, current profitability, and lagged economic growth affect credit risk is remarkably different in the Islamic banking industry than in the conventional banking industry.

Economica: Jurnal Ekonomi Islam - Volume 11, Nomor 2 (2020) 
This paper has several implications. The first is that the banking authorities, investors, and depositors should not take any presumption about the level of credit risk in Islamic compared to conventional banking industries. Despite the theoretical prediction, that Islamic banks suffer from adverse selection and asymmetric information, the credit risk level in Islamic banking is not necessarily higher than the level of credit risk in conventional banking. The use of profit and loss sharing schemes may induce Islamic banks to assess and discipline their partners adequately, reducing the difference between the level of credit risk in the Islamic banking industry and the conventional banking industry. Moreover, in practice, Islamic banks rely more on Murabaha than on mudarabah and musharakah, making the credit risk in Islamic banking pretty much similar to the level of credit risk in the conventional banking industry. The second implication is that, even though there is no difference in the level of Islamic banks' credit risk compared to that of conventional banks, policies aimed to envisage credit risk should be made specific to each banking industry. Several determinants affect credit risk differently in the Islamic banking industry than in the conventional banking industry. Policies ignoring such differences may, therefore, not lead to satisfactory results.

Future research needs to consider the fact that financing in Islamic and conventional banking industries consists of various elements. For example, it is common to have consumer financing, mortgage financing, and business financing (Louzis et al. 2012). Therefore, if a better understanding of the nature of credit risk in Islamic and conventional banking industries is to be achieved, analysis on credit risk associated with each of these classes would be worth doing. 
Comparing Credit Risk in Islamic and Conventional ...

\section{References}

Abedifar, Pejman, Shahid M Ebrahim, Philip Molyneux, and Amine Tarazi. 2015. "Islamic Banking And Finance: Recent Empirical Literature And Directions For Future Research." Journal of Economic Surveys 29 (4): 637-70. https://doi.org/10.1111/joes.12113.

Abedifar, Pejman, Philip Molyneux, and Amine Tarazi. 2013. "Risk in Islamic Banking." Review of Finance 17 (6): 2035-96. https://doi.org/10.1093/rof/rfs041.

Akram, Hassan, and Khalil ur Rahman. 2018. "Credit Risk Management." ISRA International Journal of Islamic Finance 10 (2): 185-205. https://doi.org/10.1108/IJIF-09-2017-0030.

Ardevol, Albert, Ferruccio Palazzesi, Gareth A. Tribello, and Michele Parrinello. 2016. "General Protein Data Bank-Based Collective Variables for Protein Folding." Journal of Chemical Theory and Computation 12 (1): 29-35. https://doi.org/10.1021/acs.jctc.5b00714.

Banerjee, Abhijit V. 1997. "A Theory of Misgovernance." The Quarterly Journal of Economics 112 (4): 1289-1332. https://doi.org/10.1162/003355300555484.

Barry, Thierno Amadou, Laetitia Lepetit, and Amine Tarazi. 2011. "Ownership Structure and Risk in Publicly Held and Privately Owned Banks." Journal of Banking \& Finance $35 \quad$ (5): 1327-40. https://doi.org/10.1016/j.jbankfin.2010.10.004.

Barth, James R, Gerard Caprio, and Ross Levine. 2004. "Bank Regulation and Supervision: What Works Best?" Journal of Financial Intermediation 13 (2): 205-48. https://doi.org/10.1016/j.jfi.2003.06.002.

Beck, Thorsten, Asli Demirgüç-Kunt, and Ouarda Merrouche. 2013. "Islamic vs. Conventional Banking: Business Model, Efficiency and Stability." Journal of Banking \& Finance $37 \quad$ (2): 433-47. https://doi.org/10.1016/j.jbankfin.2012.09.016.

Berger, Allen N., and Robert DeYoung. 1997. "Problem Loans and Cost Efficiency in Commercial Banks." Journal of Banking \& Finance 21 (6): 849-70. https://doi.org/10.1016/S0378-4266(97)00003-4.

Boudriga, Abdelkader, Neila Boulila Taktak, and Sana Jellouli. 2009. "Banking Supervision and Nonperforming Loans: A Cross-country Analysis."

Economica: Jurnal Ekonomi Islam - Volume 11, Nomor 2 (2020) 
Akhmad Akbar Susamto, Danes Quirira Octavio, and Dyah Titis Kusuma Wardani

Journal of Financial Economic Policy 1 (4): 286-318. https://doi.org/10.1108/17576380911050043.

Brown, Craig O, and I Serdar Dinç. 2011. "Too Many to Fail? Evidence of Regulatory Forbearance When the Banking Sector Is Weak." Review of Financial $\quad$ Studies $24 \quad$ (4): $\quad$ 1378-1405. https://doi.org/10.1093/rfs/hhp039.

Chaibi, Hasna, and Zied Ftiti. 2015. "Credit Risk Determinants: Evidence from a Cross-Country Study." Research in International Business and Finance 33 (January): 1-16. https://doi.org/10.1016/j.ribaf.2014.06.001.

Cornett, Marcia Millon, Lin Guo, Shahriar Khaksari, and Hassan Tehranian. 2010. "The Impact of State Ownership on Performance Differences in Privately-Owned versus State-Owned Banks: An International Comparison." Journal of Financial Intermediation 19 (1): 74-94. https://doi.org/10.1016/j.jfi.2008.09.005.

Dimitrios, Anastasiou, Louri Helen, and Tsionas Mike. 2016. "Determinants of Non-Performing Loans: Evidence from Euro-Area Countries." Finance $\begin{array}{llll}\text { Research } & \text { Letters } & 18 & \text { (10): }\end{array}$ https://doi.org/10.1016/j.frl.2016.04.008.

Elgari, Mohamed. 2003. "Credit Risk in Islamic Banking and Finance." Islamic Economic Studies 10 (2): 1-25. https://ssrn.com/abstract=3164227.

Errico, Luca, and Mitra Farahbaksh. 2001. "Islamic Banking: Issues in Prudential Regulation and Supervision." Journal of King Abdulaziz University-Islamic Economics, IMF Working Paper, 13 (1): 27-68. https://doi.org/10.4197/islec.13-1.7.

Espinoza, Raphael, and Ananthakrishnan Prasad. 2010. "Nonperforming Loans in the GCC Banking System and Their Macroeconomic Effects." IMF $\begin{array}{lllll}\text { Working } & \text { Papers } & 10 & \text { (224): } & 1 .\end{array}$ https://doi.org/10.5089/9781455208890.001.

Fatihah, K J Nurul, Universiti Kebangsaan, and Plaza Permata. 2019. “EquityBased Financing and Liquidity Risk: Insights from Malaysia and Indonesia." International Journal of Economics, Management and Accounting $27 \quad$ (2): 291-313. https://journals.iium.edu.my/enmjournal/index.php/enmj/article/vie $\mathrm{w} / 706$. 
Fofack, Hippolyte. 2005. "Nonperforming Loans in Sub-Saharan Africa: Causal Analysis and Macroeconomic Implications." World Bank Policy Research Working Paper, 1-36. https://ssrn.com/abstract=849405.

Ghosh, Amit. 2015. "Banking-Industry Specific and Regional Economic Determinants of Non-Performing Loans: Evidence from US States." Journal of Financial Stability 20 (October): 93-104. https://doi.org/10.1016/j.jfs.2015.08.004.

Ghosh, Saibal. 2015. "Credit Growth and Macroprudential Regulation: Is Ownership Important?" Edited by Dr S. K. Shanthi, Dr. Vinay Kumar Nang. International Journal of Law and Management 57 (3): 167-82. https://doi.org/10.1108/IJLMA-02-2014-0008.

Hart, Oliver, Andrei Shleifer, and Robert W. Vishny. 1997. "The Proper Scope of Government: Theory and an Application to Prisons." The Quarterly Journal of Economics 112 (4): 1127-61. https://doi.org/10.1162/003355300555448.

Iannotta, Giuliano, Giacomo Nocera, and Andrea Sironi. 2007. "Ownership Structure, Risk and Performance in the European Banking Industry." Journal of Banking \& Finance 31 (7): 2127-49. https://doi.org/10.1016/j.jbankfin.2006.07.013.

___ 2013. "The Impact of Government Ownership on Bank Risk." Journal of Financial Intermediation 22 (2): 152-76. https://doi.org/10.1016/j.jfi.2012.11.002.

Jensen, Michael C, and William H Meckling. 1976. "Theory of the Firm: Managerial Behavior, Agency Costs and Ownership Structure." Journal of Financial Economics 3 (4): 305-60. https://doi.org/10.1016/0304405X(76)90026-X.

Jimenez, Gabriel, and Jesús Saurina. 2006. "Credit Cycles , Credit Risk , and Prudential Regulation *." International Journal of Central Banking 2: 6598.

Johansson, Magnus, Tingting Tan, Karin E. de Visser, and Lisa M. Coussens. 2007. "Immune Cells as Anti-Cancer Therapeutic Targets and Tools." Journal of Cellular Biochemistry 101 (4): 918-26. https://doi.org/10.1002/jcb.21230.

Junarsin, E., and F. Ismiyanti. 2009. "Corporate Governance in Indonesian Banking Industry" 3 (2): 131-40. https://ssrn.com/abstract=1629462.

Economica: Jurnal Ekonomi Islam - Volume 11, Nomor 2 (2020) 
Akhmad Akbar Susamto, Danes Quirira Octavio, and Dyah Titis Kusuma Wardani

Kabir, Md Nurul, Andrew Worthington, and Rakesh Gupta. 2015. "Comparative Credit Risk in Islamic and Conventional Bank." PacificBasin Finance Journal 34 (September): 327-53. https://doi.org/10.1016/j.pacfin.2015.06.001.

Keeton, William R. 1999. "Does Faster Loan Growth Lead to Higher Loan Losses?" Federal Reserve Bank of Kansas City Economic Review, 57-75.

Khan, Feisal. 2010. "How 'Islamic' Is Islamic Banking?" Journal of Economic Behavior \& Organization 76 (3): $805-20$. https://doi.org/10.1016/j.jebo.2010.09.015.

Klein, Nir. 2013. "Non-Performing Loans in CESEE: Determinants and Impact on Macroeconomic Performance." IMF Working Papers 13 (72): 1. https://doi.org/10.5089/9781484318522.001.

Lassoued, Mongi. 2018. "Comparative Study on Credit Risk in Islamic Banking Institutions: The Case of Malaysia." The Quarterly Review of Economics and Finance 70 (November): https://doi.org/10.1016/j.qref.2018.05.009.

Lawrence, Emily C. 1995. "Consumer Default and the Life Cycle Model." Journal of Money, Credit and Banking 27 (4): 939. https://doi.org/10.2307/2077781.

López-Espinosa, Germán, Antonio Moreno, and Fernando Pérez de Gracia. 2011. 'Banks' Net Interest Margin in the 2000s: A Macro-Accounting International Perspective." Journal of International Money and Finance 30 (6): 1214-33. https://doi.org/10.1016/j.jimonfin.2011.06.001.

Louhichi, Awatef, and Younes Boujelbene. 2016. "Credit Risk, Managerial Behaviour and Macroeconomic Equilibrium within Dual Banking Systems: Interest-Free vs. Interest-Based Banking Industries." Research in International Business and Finance 38 (September): 104-21. https://doi.org/10.1016/j.ribaf.2016.03.014.

Louzis, Dimitrios P., Angelos T. Vouldis, and Vasilios L. Metaxas. 2012. "Macroeconomic and Bank-Specific Determinants of Non-Performing Loans in Greece: A Comparative Study of Mortgage, Business and Consumer Loan Portfolios." Journal of Banking \& Finance 36 (4): 101227. https://doi.org/10.1016/j.jbankfin.2011.10.012.

Misman, Faridah Najuna, Ishaq Bhatti, Weifang Lou, Syamsyul Samsudin, and Nor Hadaliza Abd Rahman. 2015. "Islamic Banks Credit Risk: A Panel 
Study." Procedia Economics and Finance 31 (15): 75-82. https://doi.org/10.1016/S2212-5671(15)01133-8.

Munn, A. S., P. W. Dunne, S. V. Y. Tang, and E. H. Lester. 2015. "Large-Scale Continuous Hydrothermal Production and Activation of ZIF-8." Chemical Communications 51 (64): 12811-14. https://doi.org/10.1039/C5CC04636J.

Naili, Maryem, and Younes Lahrichi. 2020. "The Determinants of Banks' Credit Risk: Review of the Literature and Future Research Agenda." International Journal of Finance \& Economics, no. June (August): iffe.2156. https://doi.org/10.1002/ijfe.2156.

Nkusu, Mwanza. 2011. "Nonperforming Loans and Macrofinancial Vulnerabilities in Advanced Economies." IMF Working Papers 11 (161): 1. https://doi.org/10.5089/9781455297740.001.

Onmus-Baykal, Elif. 2010. "A Literature Review of Credit." Georgetown University, no. July: 1-26.

Podpiera, Jiří, and Laurent Weill. 2008. "Bad Luck or Bad Management? Emerging Banking Market Experience." Journal of Financial Stability 4 (2): 135-48. https://doi.org/10.1016/j.jfs.2008.01.005.

Quagliariello, Mario. 2007. “Banks' Riskiness over the Business Cycle: A Panel Analysis on Italian Intermediaries." Applied Financial Economics 17 (2): 119-38. https://doi.org/10.1080/09603100500486501.

Reinhart, Carmen M., and Kenneth S. Rogoff. 2010. "Summary for Policymakers." In Climate Change 2013 - The Physical Science Basis, edited by Intergovernmental Panel on Climate Change, 1-30. Cambridge: Cambridge University

Press. https://doi.org/10.1017/CB09781107415324.004.

Rinaldi, Laura, and Alicia Sanchis-arellano. 2006. "Household Debt Sustainability: What Explains Household Non-Performing Loans? An Empirical Analysis." European Central Bank: Working Paper Series. https://econpapers.repec.org/paper/ecbecbwps/2006570.htm.

Salas, Vicente, and Jesús Saurina. 2002. "Credit Risk in Two Institutional Regimes: Spanish Commercial and Savings Banks." Journal of Financial Services Research 22 (3): 203-24. https://doi.org/10.1023/A:1019781109676. 
Samad, Abdus, Norman D. Gardner, and Bradley J. Cook. 2005. "Islamic Banking and Finance in Theory and Practice." American Journal of Islamic Social Sciences 22 (2): 69-86. https://doi.org/10.35632/ajiss.v22i2.458.

Shehzad, Choudhry Tanveer, Jakob de Haan, and Bert Scholtens. 2010. "The Impact of Bank Ownership Concentration on Impaired Loans and Capital Adequacy." Journal of Banking \& Finance 34 (2): 399-408. https://doi.org/10.1016/j.jbankfin.2009.08.007.

Stern, Gary H., and Ron J. Feldman. 2004. "Too Big to Fail: The Hazards of Bank Bailouts." Choice Reviews Online 42 (02): 42-1064-42-1064. https://doi.org/10.5860/CHOICE.42-1064.

Stiroh, Kevin J. 2004. "Diversification in Banking: Is Noninterest Income the Answer ?" Journal of Money, Credit and Banking 36 (5): 853-82.

Tripodi, Miriam Potocky. 2001. "Micro and Macro Determinants of Refugee Economic Status." Journal of Social Service Research 27 (4): 33-60. https://doi.org/10.1300/J079v27n04_02.

Zribi, Nabila, and Younes Boujelbène. 2011. "The Factors Influencing Bank Credit Risk: The Case of Tunisia." Journal of Accounting and Taxation 3 (4): 70-78. 